\title{
Distribution and Abundance Estimates for Cetaceans in the Waters off Guam and the Commonwealth of the Northern Mariana Islands ${ }^{1}$
}

\author{
Gregory L. Fulling, ${ }^{2,5}$ Philip H. Thorson, ${ }^{3}$ and Fulie Rivers ${ }^{4}$
}

\begin{abstract}
Cetacean distribution and abundance are reported from the first systematic line-transect visual survey in the waters of Guam and the Commonwealth of the Northern Mariana Islands (CNMI). The survey was conducted during January-April 2007 following standard line-transect protocols. Trackline coverage $(11,033 \mathrm{~km})$ was dominated by high sea states $(88.2 \%)$; however, 13 cetacean species were recorded. The sperm whale (Physeter macrocephalus) was the most frequently encountered whale, followed by Bryde's and sei whales (Balaenoptera edeni and B. borealis, respectively). Occurrence of the sei whale is unique, because the species had not been confirmed to occur south of $20^{\circ} \mathrm{N}$. The pantropical spotted dolphin (Stenella attenuata) was the most frequently sighted delphinid, followed by the striped dolphin (Stenella coeruleoalba) and false killer whale (Pseudorca crassidens). Humpback whales (Megaptera novaeangliae) were acoustically detected and later seen off Saipan. Numerous cetacean sightings were associated with steep bathymetric features including the West Mariana Ridge, the Mariana Ridge, and the Mariana Trench. Abundance estimates were based on 80 on-effort sightings for 12 species. Species were pooled into three separate groups for estimating detection probabilities: Balaenoptera spp., blackfish (medium-size odontocetes), and small dolphins. A separate detection function was generated for the sperm whale. Precision of abundance estimates are very low for all species due to low sighting rates and high sea states; however, these abundance estimates serve as the best scientific data available for the area and establish vital baseline information for future research efforts.
\end{abstract}

Marine mammal species richness and distribution in the waters around Guam and the Commonwealth of the Northern Mariana

\footnotetext{
${ }^{1}$ Funding for this survey was provided by the Commander, U.S. Pacific Fleet. This paper represents the independent and original work of the authors and does not represent the position of the U.S. Navy or Department of Defense. Manuscript accepted 20 September 2010.

${ }^{2}$ Geo-Marine, Inc., $2201 \mathrm{~K}$ Avenue, Suite A2, Plano, Texas 75074. Current address: HDR/EOC, 500 108th Avenue N.E., Suite 1200, Bellevue, Washington 980045549 (phone: 425-647-8776; fax: 425-453-7107; e-mail: gregory.fulling@hdrinc.com).

${ }_{3}^{3}$ ManTech SRS, Long Marine Laboratory, 100 Shaffer Road, Santa Cruz, California 95060.

${ }^{4}$ U.S. Pacific Fleet Environmental Readiness Office, 250 Makalapa Drive, Pearl Harbor, Hawai'i 96860.

${ }_{5}^{5}$ Corresponding author.
}

Pacific Science (2011), vol. 65, no. 3:321-343

doi: $10.2984 / 65.3 .321$

(C) 2011 by University of Hawai'i Press

All rights reserved
Islands (CNMI) are not well known. Most accounts of marine mammal occurrence within the region are opportunistically reported sighting and stranding data (reviewed in Department of the Navy [2005]). In 1949, Japanese agencies involved in the management of whaling began a research program of marking (tagging) in the North Pacific Ocean (Omura and Kawakami 1956, Ohsumi and Masaki 1975). Many thousands of whales from several regions of the western Pacific were marked by shooting metal tags into the animals with the hope of recovering those tags once the animals were captured and flensed. Data from those tags provided information on the movement of the animals (Omura and Kawakami 1956, Masaki 1972, Miyazaki and Wada 1978, Shimada and Miyashita 2001, Ohizumi et al. 2002, Shimada et al. 2008). Eldredge (1988) provided the first compilation of published and unpublished records for marine mammals occurring in Micronesia. Information on 18 
species of marine mammals was documented in that report and made publicly available as a peer-reviewed publication by Eldredge (1991). Kami and Lujan (1976), Kami and Hosmer (1982), Donaldson (1983), Trianni and Kessler (2002), Eldredge (2003), Wiles (2005), and Jefferson et al. (2006) provided additional published records for this region.

The aforementioned reports have contributed to the information of marine mammals in Guam and CNMI, but the data are still sparse. The lack of valid scientific data on cetacean species richness and distribution for the Mariana archipelago is problematic for the management of the resources covered under the Marine Mammal Protection Act (MMPA), Endangered Species Act (ESA), and National Environmental Policy Act (NEPA). The Marine Resources Assessment (MRA) for the Mariana Islands Operating Area (Department of the Navy 2005) presented 32 marine mammal species that were considered to potentially frequent these waters, based largely on scientific inference using occurrence records (i.e., sightings, strandings), known habitat preferences, and distribution of Pacific marine mammals (Table 1). Data shortfalls demonstrated in the MRA led the Navy to seek to fill the data gaps and improve those data used for environmental planning purposes.

We present the results of the first systematic line-transect visual survey in the waters of Guam and CNMI: Mariana Islands Sea Turtle and Cetacean Survey (MISTCS). This systematic shipboard survey was designed to assist the Navy in preparing environmental compliance documents by: (1) collecting data on the species richness and distribution of cetaceans and sea turtles in waters around Guam and CNMI; and (2) generating density estimates for those species having adequate data in the region of interest to the Navy.

The bathymetry of the region is exemplified by its steeply sloping bottom with depths dropping rapidly near the islands in the archipelago. Two volcanic arcs, the West Mariana Ridge (a remnant volcanic arc than runs from approximately $21^{\circ} \mathrm{N}, 142^{\circ} \mathrm{E}$ to $11^{\circ} 30^{\prime} \mathrm{N}$, $141^{\circ} \mathrm{E}$ ) and the Mariana Ridge (an active volcanic arc), are separated by the Mariana Trough. The Mariana archipelago is located on the Mariana Ridge. The Mariana archipelago comprises 15 volcanic islands including Guam, Rota, Tinian, and Saipan. The Mariana Trench is over 2,270 km long and $114 \mathrm{~km}$ wide, with the deepest point in the trench (and on the planet), Challenger Deep, being found $544 \mathrm{~km}$ southwest of Guam in the southwestern extremity of the trench. The Mariana Ridge is located to the west of the trench (although east of the Challenger Deep) and is surrounded by numerous seamounts. To the southeast of the Mariana Trench is the Caroline Ridge, which extends in an ESE direction (Figure 1).

The general oceanic circulation within the study area and the Mariana Islands is poorly understood due to the paucity of large-scale oceanographic research conducted there (Sandwell et al. 2003). Surface currents within the study area are heavily influenced by the North Pacific Equatorial Current (NPEC) and the North Equatorial Current (NEC), which is driven by trade winds (Pickard and Emery 1982, Wolanski et al. 2003). The result is a net transport west/northwest (Uda 1970, Wolanski et al. 2003). The passage of the NEC through the Mariana archipelago can create regions of enhanced turbulence, capable of entraining phytoplankton and creating localized regions of enhanced primary production visible as increased concentrations of chlorophyll $a$ in the surface waters (Gilmartin and Revelante 1974, Simpson et al. 1982, Wolanski et al. 2003). The MISTCS study area lies within an oceanic province with generally very low levels of primary productivity due to low-latitude nutrients being transported to North Pacific waters (see Sarmiento et al. 2004). Therefore, any areas with increased primary productivity can attract all components of the local food chain and thereby create "hot spots" of resources and concentrations of predators (see Palacios et al. 2006). Strong interactions between the local oceanography and topography exist in the study area. In general, seamount topography is correlated with enhanced production due to the formation of vortices capable of mixing nutrients to the surface and entraining phytoplankton in the overlying waters (Genin and Dower 2007). 
TABLE 1

Marine Mammal Species of Guam and CNMI from Literature Compilation (Department of the Navy 2005)

\begin{tabular}{|c|c|c|}
\hline Taxon & Scientific Name & Occurrence $^{a}$ \\
\hline \multicolumn{3}{|l|}{ Order Cetacea } \\
\hline \multicolumn{3}{|l|}{ Suborder Mysticeti } \\
\hline \multicolumn{3}{|l|}{ Family Balaenidae } \\
\hline North Pacific right whale & Eubalaena japonica $^{b}$ & Rare \\
\hline \multicolumn{3}{|l|}{ Family Balaenopteridae } \\
\hline Humpback whale & Megaptera novaeangliae ${ }^{b}$ & Regular \\
\hline Minke whale & Balaenoptera acutorostrata & Rare \\
\hline Sei whale & Balaenoptera borealis ${ }^{b}$ & Extralimital \\
\hline Fin whale & Balaenoptera physalus ${ }^{b}$ & Rare \\
\hline Blue whale & Balaenoptera musculus ${ }^{b}$ & Rare \\
\hline Bryde's whale & Balaenoptera edeni/brydei ${ }^{c}$ & Regular \\
\hline \multicolumn{3}{|l|}{ Suborder Odontoceti } \\
\hline \multicolumn{3}{|l|}{ Family Physeteridae } \\
\hline Sperm whale & Physeter macrocephalus ${ }^{b}$ & Regular \\
\hline \multicolumn{3}{|l|}{ Family Kogiidae } \\
\hline Pygmy sperm whale & Kogia breviceps & Regular \\
\hline Dwarf sperm whale & Kogia sima & Regular \\
\hline \multicolumn{3}{|l|}{ Family Ziphiidae } \\
\hline Cuvier's beaked whale & Ziphius cavirostris & Regular \\
\hline Blainville's beaked whale & Mesoplodon densirostris & Regular \\
\hline Ginkgo-toothed beaked whale & Mesoplodon ginkgodens & Rare \\
\hline Hubbs' beaked whale & Mesoplodon carlhubbsi & Extralimital \\
\hline Longman's beaked whale & Indopacetus pacificus & Regular \\
\hline \multicolumn{3}{|l|}{ Family Delphinidae } \\
\hline Rough-toothed dolphin & Steno bredanensis & Regular \\
\hline Bottlenose dolphin & Tursiops truncatus & Regular \\
\hline Indo-Pacific bottlenose dolphin & Tursiops aduncus & Extralimital \\
\hline Pantropical spotted dolphin & Stenella attenuata & Regular \\
\hline Spinner dolphin & Stenella longirostris & Regular \\
\hline Striped dolphin & Stenella coeruleoalba & Regular \\
\hline Short-beaked common dolphin & Delphinus delphis & Rare \\
\hline Risso's dolphin & Grampus griseus & Regular \\
\hline Melon-headed whale & Peponocephala electra & Regular \\
\hline Fraser's dolphin & Lagenodelphis bosei & Regular \\
\hline Pygmy killer whale & Feresa attenuata & Regular \\
\hline False killer whale & Pseudorca crassidens & Regular \\
\hline Killer whale & Orcinus orca & Regular \\
\hline Short-finned pilot whale & Globicephala macrorbynchus & Regular \\
\hline \multicolumn{3}{|l|}{ Order Carnivora } \\
\hline \multicolumn{3}{|l|}{ Suborder Pinnipedia } \\
\hline \multicolumn{3}{|l|}{ Family Phocidae } \\
\hline Hawaiian monk seal & Monachus schauinslandi ${ }^{b}$ & Extralimital \\
\hline Northern elephant seal & Mirounga angustirostris ${ }^{b}$ & Extralimital \\
\hline \multicolumn{3}{|l|}{ Order Sirenia } \\
\hline \multicolumn{3}{|l|}{ Family Dugongidae } \\
\hline Dugong & Dugong dugon & Extralimital \\
\hline
\end{tabular}




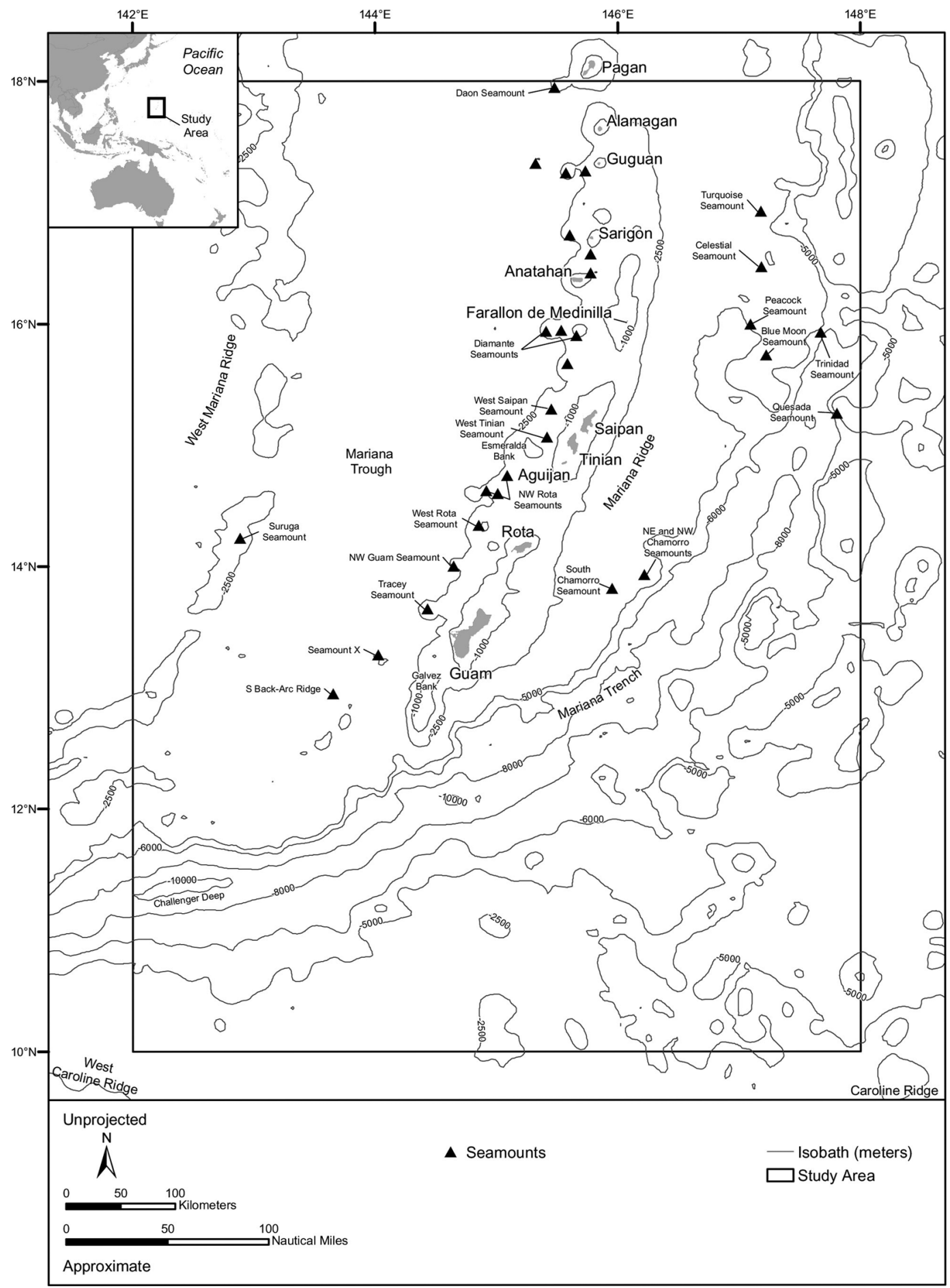

FIGURE 1. Bathymetry and key oceanographic features of the MISTCS study area located in Guam and CNMI waters. 
MATERIALS AND METHODS

\section{Study Area}

The MISTCS study area is a $\sim 310,300 \mathrm{~km}^{2}$ rectangle bounded by $18^{\circ}-10^{\circ} \mathrm{N}$ and $142^{\circ}-$ $148^{\circ} \mathrm{E}$ (Figure 1). This region is characterized by an archipelago where the dominant oceanographic features are the Mariana Trench, Mariana Trough, ridges, seamounts, hydrothermal vents, and submarine volcanoes.

\section{Field Techniques}

Visual line-transect survey methods (Buckland et al. 2001, 2004) were used from the $56.4 \mathrm{~m} \mathrm{M} / \mathrm{V}$ Kabana and were fundamentally identical to those used during Southwest Fisheries Science Center (SWFSC of the National Marine Fisheries Service [NMFS]) surveys. This survey was conducted from 16 January to 13 April 2007 (boreal winter) and divided into four legs ( 21 days per leg); all port calls were at Apra Harbor, Guam. Survey tracklines were oriented to maximize visual effort depending on wind, waves, and swell and decrease traveling broadside to and straight into dominant swells. Trackline effort was not stratified, because there was little information on the region to base stratification of effort. The dominant winds were consistently ENE. Start location within the area of operation (north or south) was determined by a flip of a coin at the beginning of the survey and alternated each leg. Tracklines were sometimes modified, depending on the effect of the vessel's ride (pitch, yaw, and roll) to improve observer stability on the flying bridge. However, deviation did not exceed $9.3 \mathrm{~km}$ from the original course before reorienting the vessel's direction. Survey speed was usually $16.7-18.5 \mathrm{~km} / \mathrm{hr}$, but varied with sea conditions.

Visual survey effort was conducted from the flying bridge (with observers' eye height $10.5 \mathrm{~m}$ above the water's surface), beginning at sunrise and continuing until sunset each day, weather-permitting (i.e., no rain, Beaufort sea state $<7$ ). The daily watch consisted of six observers who were experienced in NMFS survey techniques and Pacific species identification. Observers rotated through a port-side
$25 \times$ binocular station, a data recorder position, and a starboard-side $25 \times$ binocular station with $40 \mathrm{~min}$ per station. The left- and right-side observers searched to the horizon in an arc from $\sim 10^{\circ}$ right and left of the ship's bow to the left and right beams $\left(90^{\circ}\right)$, respectively, using $25 \times$ pedestal-mounted binoculars. The third observer searched the forward $180^{\circ}$ using unaided eye or $7 \times$ hand-held binoculars and recorded data. Each observer worked a 2 -hr shift followed by a 2 -hr rest period. Requests for alterations to the ship's course or speed were conveyed to the bridge by the visual observer team. If Beaufort sea state was too high, observers switched to hand-held binoculars, naked-eye effort, or in worst-case scenarios, one person rotated as a bridge watch. Data collected in this manner were not used to estimate abundance, only distribution.

Data were recorded on a computer interfaced with an independent global positioning system (GPS) via a custom data acquisition program (WinCruz NMFS/SWFSC). For each sighting, the time, position, bearing and reticle (a measure of radial distance) of the sighting, species, and associated animals (e.g., seabirds, fish) were recorded. For groups sighted without $25 \times$ binoculars and close to the ship, the bearing and radial distance were estimated. Survey effort data were automatically recorded every $10 \mathrm{~min}$ and for every sighting. Data recorded included the ship's position, effort status, observer positions, and environmental conditions, which could affect the observers' ability to sight animals (e.g., high sea state, glare, sun position). Typically, if a sighting was within a $5.5 \mathrm{~km}$ strip on either side of the ship, the ship was diverted from the trackline to approach the group to identify species and estimate group size. Cetaceans were identified to the lowest taxonomic level possible. Observers' ability to make identifications depended on weather and animal behavior. Independent group size estimates (best, high, and low) were made by each observer and recorded for later entry into the database. The ship was directed to make course and speed changes as deemed appropriate to maximize the viewing and photography of the groups. Once a group size estimate, 
species identification, and photography were completed, the ship was directed to return to course and speed.

In addition to visual survey operations, a two-element hydrophone array was towed from the M/V Kabana during daylight hours to detect acoustic signals from vocalizing cetaceans (Norris et al. 2007). The acoustics team worked independent of the visual team. If an acoustic detection was not acquired visually, the visual team was notified once the detection passed the beam. On several occasions, the ship was diverted to acquire the acoustic detection. Most diversions were for sperm or minke whales (Physeter macrocephalus and Balaenoptera acutorostrata, respectively). Animals acoustically detected but missed by the visual team were not included in distribution or abundance estimation analyses for this paper and no acoustic "cues" were used to enhance visual sightings.

\section{Analytical Techniques}

For each species, genus, or unidentified category $(i)$, abundance $\left(N_{i}\right)$ was estimated with line-transect methods using the program DISTANCE (Thomas et al. 2006) by:

$$
N_{i}=\frac{A n_{i} S_{i} f_{i}(0)}{2 L_{i} g(0)}
$$

where $A=$ area of the study area, $n_{i}=$ number of group sightings of species $i, S_{i}=$ mean group size of species $i, f_{i}(0)=$ sighting probability density function at perpendicular distance zero for species $i, L=$ total length of transect line, and $g(0)=$ probability of seeing a group on the transect line.

The parameter $g(0)$ was not estimated on this survey, and $g(0)=1$ was assumed (see section on Abundance in Discussion). The lognormal $95 \%$ confidence interval (CI) was computed for each abundance/density estimate (Buckland et al. 2001). The variance of $N_{i}$ was estimated as:

$$
\begin{aligned}
\operatorname{var}\left(N_{i}\right) \\
\quad=N_{i}^{2} \cdot\left\{\frac{\operatorname{var}\left(n_{i}\right)}{n_{i}^{2}}+\frac{\operatorname{var}\left(S_{i}\right)}{S_{i}^{2}}+\frac{\operatorname{var}\left[\hat{f}_{i}(0)\right]}{\left[\hat{f}_{i}(0)\right]^{2}}\right\} .
\end{aligned}
$$

The sampling unit was the length of transect completed on-effort each day with Beaufort sea state $\leq 6$. The formula used to estimate each component of the variance followed Buckland et al. (2001, 2004). A transectlength-weighted $\operatorname{var}\left(n_{i}\right)$ was based on the variation in the number of on-effort group sightings between sampling units that ranged up to $239 \mathrm{~km} /$ day. Coefficients of variation $(\mathrm{CV})$ were estimated as $\mathrm{CV}\left(N_{i}\right)=\left[\operatorname{var}\left(N_{i}\right)\right]^{1 / 2} / N_{i}$ and $\mathrm{CV}\left(N_{i}\right)$ as:

$$
C V\left(N_{i}\right)=\left\{\sum C V\left(N_{i}\right)^{2}\right\}^{1 / 2} / \sum N_{i} .
$$

The perpendicular distance, $y$, for each sighting was estimated using bearing and reticle measurements. The reticle readings were converted to radial sighting distances (R) by the method of Lerczak and Hobbs (1998), using the formula $y=\mathrm{R} \sin (b)$, where $b=$ angle between the sighting and the transect line. Estimates of $f(0)$ were made using a halfnormal model with exact perpendicular sighting distances because hazard-rate models are known to give highly variable estimates (Gerrodette and Forcada 2005). Model selection was determined using Akaike's Information Criterion (Akaike 1973, Buckland et al. 2001, 2004). No covariates were used in the modeling of abundance. Although Beaufort sea state and group size would have been appropriate covariates, the low number of sightings resulted in reduced sample size thereby further decreasing the robustness of the analysis.

The group sizes for some species tended to be related to $y$, because in many cases larger groups are easier to see than small groups with increasing $y$. In general, the arithmetic mean of group size may be an overestimate of the true mean group size and could lead to positively biased density and abundance estimates (Buckland et al. 2001). Therefore, a regression of the $\log$ (group size) by $g(y)$ (variable distance) was used to estimate an "expected mean group size" (program DISTANCE). The regression-based value of expected group size was used in the abundance estimate if the slope of the relationship was significant $(P<.15$, one-tailed); otherwise the 
observed mean group size was used. $\operatorname{Var}\left(S_{i}\right)$ was the analytical variance for mean group sizes based on arithmetic means or was estimated as in Buckland et al. (2001, 2004) for expected mean group sizes.

\section{Species/Species Groupings}

The number of groups sighted for most species was insufficient to obtain species-specific estimates of $f(0)$. Therefore, sightings of species with similar sighting characteristics (i.e., body size, group size, surface behavior, blow visibility) were pooled to estimate $f(0)$ (Barlow 1995, Mullin and Fulling 2004). The abundance for each species was estimated using the pooled $f(0)$ and $\operatorname{var}[f(0)]$ for its category (Thomas et al. 2006). This was done for three categories: Balaenoptera spp. $(n=3)$, blackfish (medium-size odontocetes; $n=4$ ), and small dolphins $(n=7)$. This was done because there were insufficient numbers of sightings for all other species to model the detection function ( $<20$ sightings) independently. Sperm whales were not pooled with any other whale species due to their propensity for long dive intervals (Barlow 1999, Barlow and Taylor 2005), general behavioral patterns, and large body size. Balaenoptera spp., which includes the sei and Bryde's whales, were combined because their physical similarity made identification extremely difficult on some occasions. Blackfish included the false killer whale (Pseudorca crassidens), melon-headed whale (Peponocephala electra), pygmy killer whale (Feresa attenuata), and short-finned pilot whale (Globicephala macrorbynchus). Blackfish species were separated from other delphinids and pooled together based on their similar size, physical appearance, and behavior. Small dolphins were those delphinids with smaller body size $(<4 \mathrm{~m})$; this group included all Stenella spp., bottlenose dolphin (Tursiops truncatus), and rough-toothed dolphin (Steno bredanensis). All sightings of pantropical spotted dolphin were of the offshore subspecies, Stenella attenuata attenuata, and all sightings of spinner dolphin (Stenella longirostris) were of the subspecies known as Gray's, Stenella longirostris longirostris.
RESULTS

\section{Survey Effort}

The team visually surveyed $11,033 \mathrm{~km}$ of trackline with bottom depth ranging from 114 to $9,874 \mathrm{~m}$. On-effort coverage ranged from 2,200 to 3,300 km (Legs 3 and 4, respectively). The survey trackline coverage was adequate given the high Beaufort sea state (Figure 2). Most of the survey was conducted in Beaufort sea state $>4(66 \%)$, and the percentage of visual effort by Beaufort sea state is depicted in Figure 3. Visual effort was continued up to a Beaufort sea state of 6 . The survey was delayed due to high winds and Beaufort sea state on several days during Legs 1 and 2. Leg 3 was stopped after 2 days due to Beaufort sea state $>7$; the ship returned to Guam during the poor weather and resumed the survey after 4 days. Leg 4 was affected by Typhoon Kong-Rey, but effort continued in the western portion of the study area to avoid the typhoon's greatest impacts. All survey effort and sightings in Beaufort sea state $\leq 6$ were included in abundance estimation.

\section{Sightings}

There were 120 "on-effort" cetacean sightings and 33 "off-effort" sightings made in the MISTCS study area, and 13 different species were seen (Table 2, Figures 4-8). There were also three sightings of beaked whales: two unidentified Mesoplodon and one ziphiid whale. The sperm whale was the most frequently sighted species $(n=23)$ followed by Bryde's and sei whales $(n=18$ and 16 , respectively; Balaenoptera edeni and B. borealis, respectively). The offshore spotted dolphin was the most frequently encountered delphinid species $(n=16)$ followed by the false killer whale and the striped dolphin (Stenella coeruleoalba) (both $n=10$ [Table 2]). Sighting parameters (e.g., group size, bottom depth) are summarized in Table 3.

Numerous sightings tended to be associated with bathymetric relief, over or near seamounts, ridges, and the Mariana Trench (Figures 4-8). Range of bottom depths for sightings were highly variable, speciesdependent, and are summarized in Table 3. 


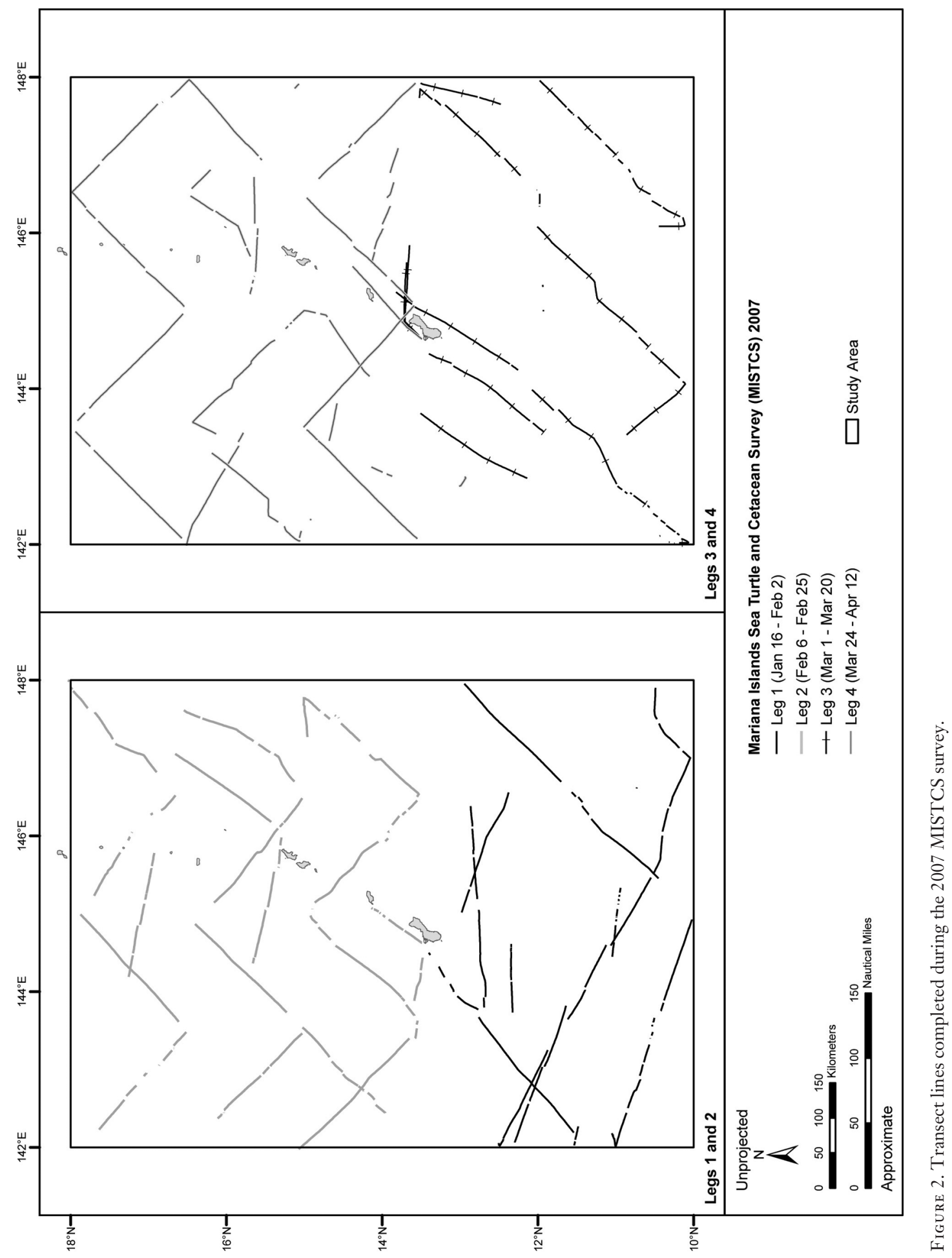




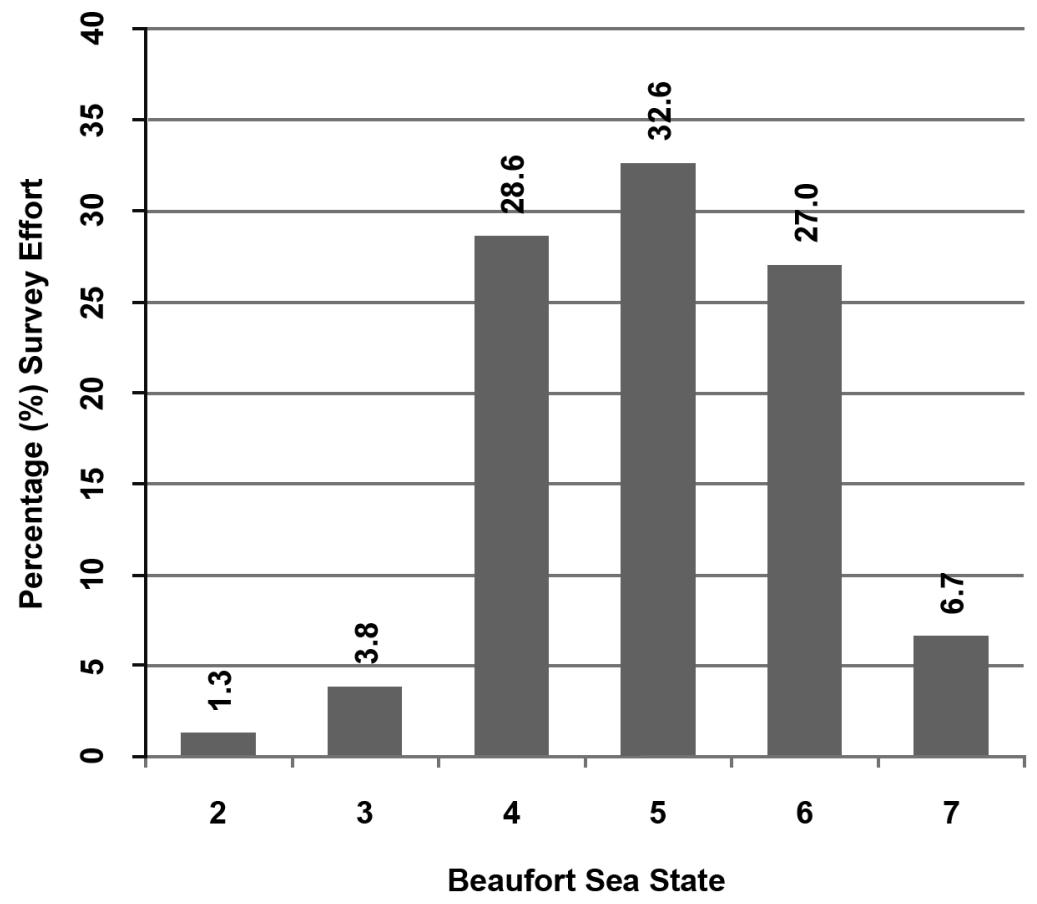

Figure 3. Percentage of survey effort stratified by Beaufort sea state during the 2007 MISTCS survey.

The vast majority of all sightings were of single species (96\%); however, seven of the 153 sightings were of mixed-species aggregations, of which four involved baleen whales. Of the four sightings, one was confirmed as two Bryde's whales with one sei whale and another was a single Bryde's whale with another whale, which could only be distinguished as Bryde's or sei. On one occasion, false killer whales were seen with a sei whale, and on another, a Bryde's whale with offshore pantropical spotted dolphins. Other mixed sightings included melon-headed whales with offshore pantropical spotted dolphins; 25 sperm whales (including calves) logging near the surface and bottlenose dolphins near the Challenger Deep; and a sighting of three cetacean species comprising short-finned pilot whales, roughtoothed dolphins, and bottlenose dolphins.

On 18 February 2007, an "off-effort" focal study of humpback whales (Megaptera novaeangliae) was conducted north of Saipan to search for humpback whales acoustically detected on 17 February. The whales were acoustically detected (singing) the previous night, calls were localized, and focal studies included photo-identification efforts. Group size was estimated to be eight individuals (Figure 6).

\section{Abundance Estimation}

Minimum abundance estimates were based on 80 "on-effort" sightings comprising 19 species or groups. Estimates of $f_{i}(0)$ for each species or group are listed in Table 4. The most abundant species included the offshore spotted dolphin, striped dolphin, melon-headed whale, and sperm whale. The precision of the abundance estimates was generally poor $(\mathrm{CV}$ $>0.30$ ) and ranged from $32.8 \%$ (Balaenoptera spp.) to $102.2 \%$ (sei/Bryde's) (Table 5). The component of the variance having the greatest amount of uncertainty in our abundance estimates was encounter rate and accounted for the largest proportion of the CVs for Balaenoptera spp. (85.5\%) and sei/Bryde's $(98.2 \%)$. Cluster size accounted for a large 
TABLE 2

Summary of Visual Sightings by Species

\begin{tabular}{|c|c|c|c|c|}
\hline Scientific Name & Common Name & On-Effort & Off-Effort & Total \\
\hline Balaenoptera borealis ${ }^{a}$ & Sei whale & 11 & 5 & 16 \\
\hline Balaenoptera edeni & Bryde's whale & 16 & 2 & 18 \\
\hline Balaenoptera borealis/edeni & & 3 & 0 & 3 \\
\hline Balaenoptera spp. & & 8 & 2 & 10 \\
\hline Megaptera novaeangliae ${ }^{a}$ & Humpback whale & 0 & 1 & 1 \\
\hline Physeter macrocephalus ${ }^{a}$ & Sperm whale & 19 & 4 & 23 \\
\hline Globicephala macrorbynchus & Short-finned pilot whale & 4 & 1 & 5 \\
\hline Peponocephala electra & Melon-headed whale & 2 & 0 & 2 \\
\hline Feresa attenuata & Pygmy killer whale & 1 & 0 & 1 \\
\hline Peponocephala/Feresa & & 1 & 1 & 2 \\
\hline Pseudorca crassidens & False killer whale & 6 & 4 & 10 \\
\hline Stenella attenuata & Pantropical spotted dolphin & 13 & 4 & 17 \\
\hline Stenella coeruleoalba & Striped dolphin & 10 & 0 & 10 \\
\hline Stenella longirostris & Spinner dolphin & 1 & 0 & 1 \\
\hline Steno bredanensis & Rough-toothed dolphin & 1 & 1 & 2 \\
\hline Tursiops truncatus & Bottlenose dolphin & 3 & 1 & 4 \\
\hline Tursiops/Steno & & 1 & 0 & 1 \\
\hline Mesoplodon spp. & Beaked whale & 2 & 0 & 2 \\
\hline Ziphiid whale & Beaked whale & 1 & 0 & 1 \\
\hline Unident. small delphinid & & 11 & 3 & 14 \\
\hline Unident. medium delphinid & & 1 & 0 & 1 \\
\hline Unident. large delphinid & & 1 & 0 & 1 \\
\hline Unident. dolphin & & 0 & 1 & 1 \\
\hline Unident. small whale & & 1 & 0 & 1 \\
\hline Unident. large whale & & 1 & 3 & 4 \\
\hline Unident. whale & & 1 & 0 & 1 \\
\hline Unident. cetacean & & 1 & 0 & 1 \\
\hline Total & & 120 & 33 & 153 \\
\hline
\end{tabular}

Note: All on- and off-effort sightings are included. Multispecies sightings are counted in each appropriate taxon. Genera separated by / indicate uncertainty in identification.

${ }^{a}$ Species protected under the Endangered Species Act.

portion of the variance $(>50 \%)$ for the sperm whale and several species of small dolphins, indicative of the importance of group size estimation, but was always accompanied by large uncertainty in encounter rate. The proportion of the variance attributed to detection probability was $<10.0 \%$ for all species or species groups.

\section{DISCUSSION}

This survey provided important information on the abundance, species richness, and distribution of the oceanic cetacean community occurring in the Guam and CNMI region. Approximately half (47\%) of all sightings were of large whale species (sperm and baleen whales). Unfortunately, Beaufort sea state was high and likely reduced the ability of detecting smaller, more common delphinid species. Failure to visually detect and/or verify species identification of the more cryptic cetaceans (Kogia spp., minke, and beaked whales) is not surprising given the high sea state of the survey (more than half of the survey was conducted in Beaufort sea state $>4$ ) and the difficulties of sighting these animals even when conditions are optimal (Beaufort sea state $<2$ ). However, in spite of the difficult sea conditions, 13 cetacean species were identified and included relatively rare sightings of sei whales.

Several species known or suspected to be within the study area were not seen on our survey; species such as Kogia spp. and minke whales are often difficult to detect during high sea states. However, Mobley (2007) 


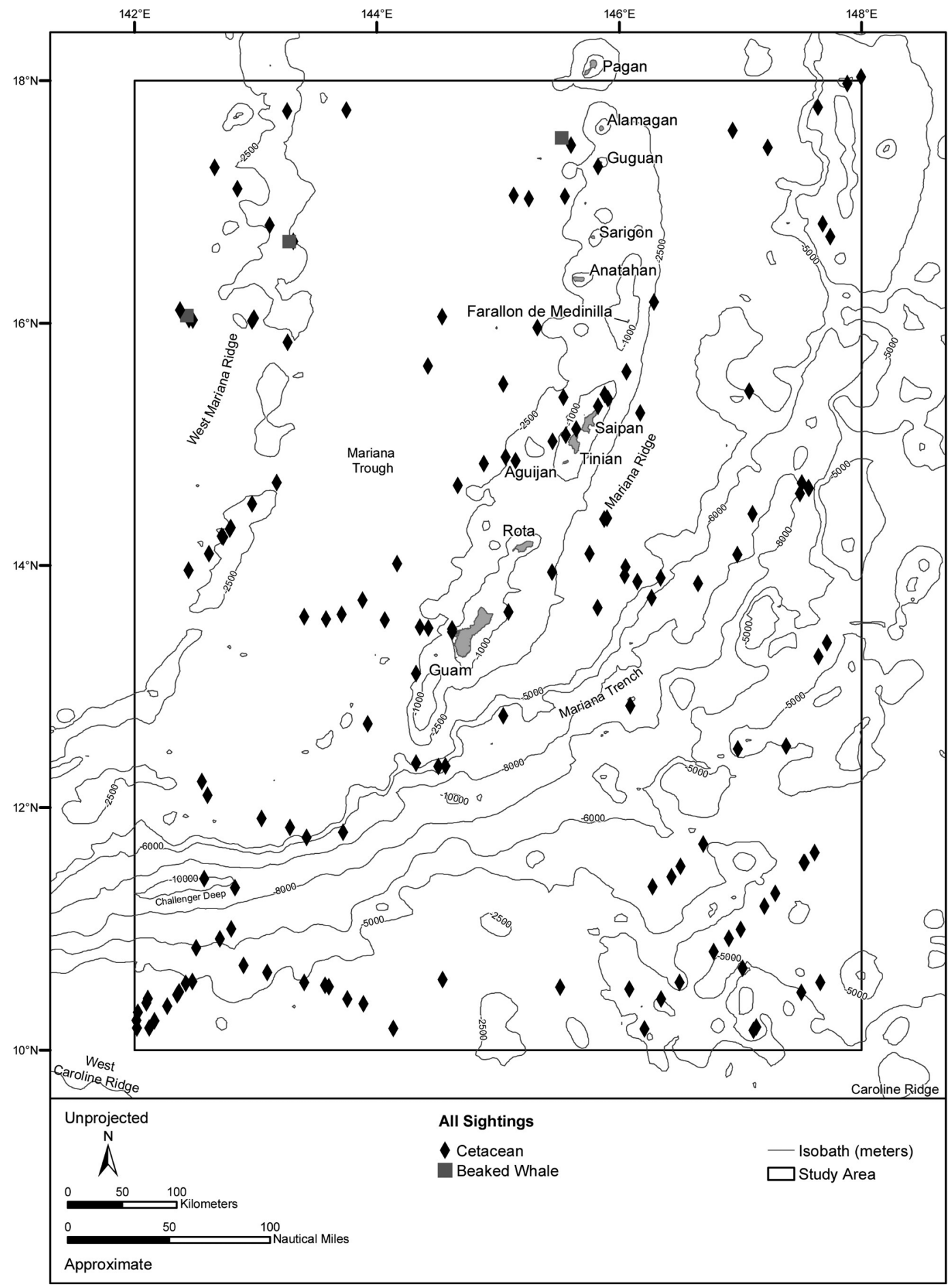

FIgURE 4. Locations of all sightings made during the 2007 MISTCS survey. 


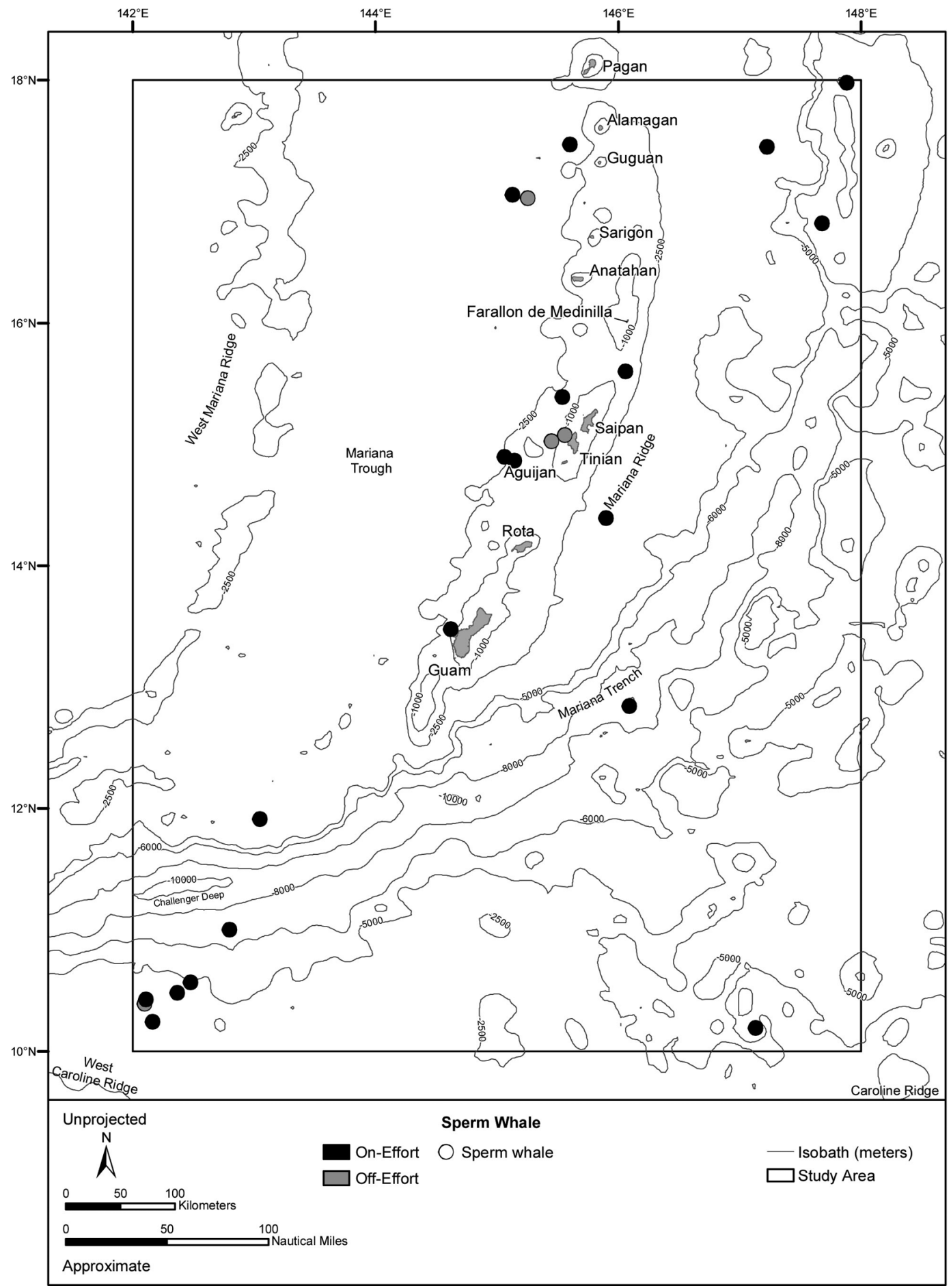

FIGURE 5. Locations of all sperm whale sightings made during the 2007 MISTCS survey. 


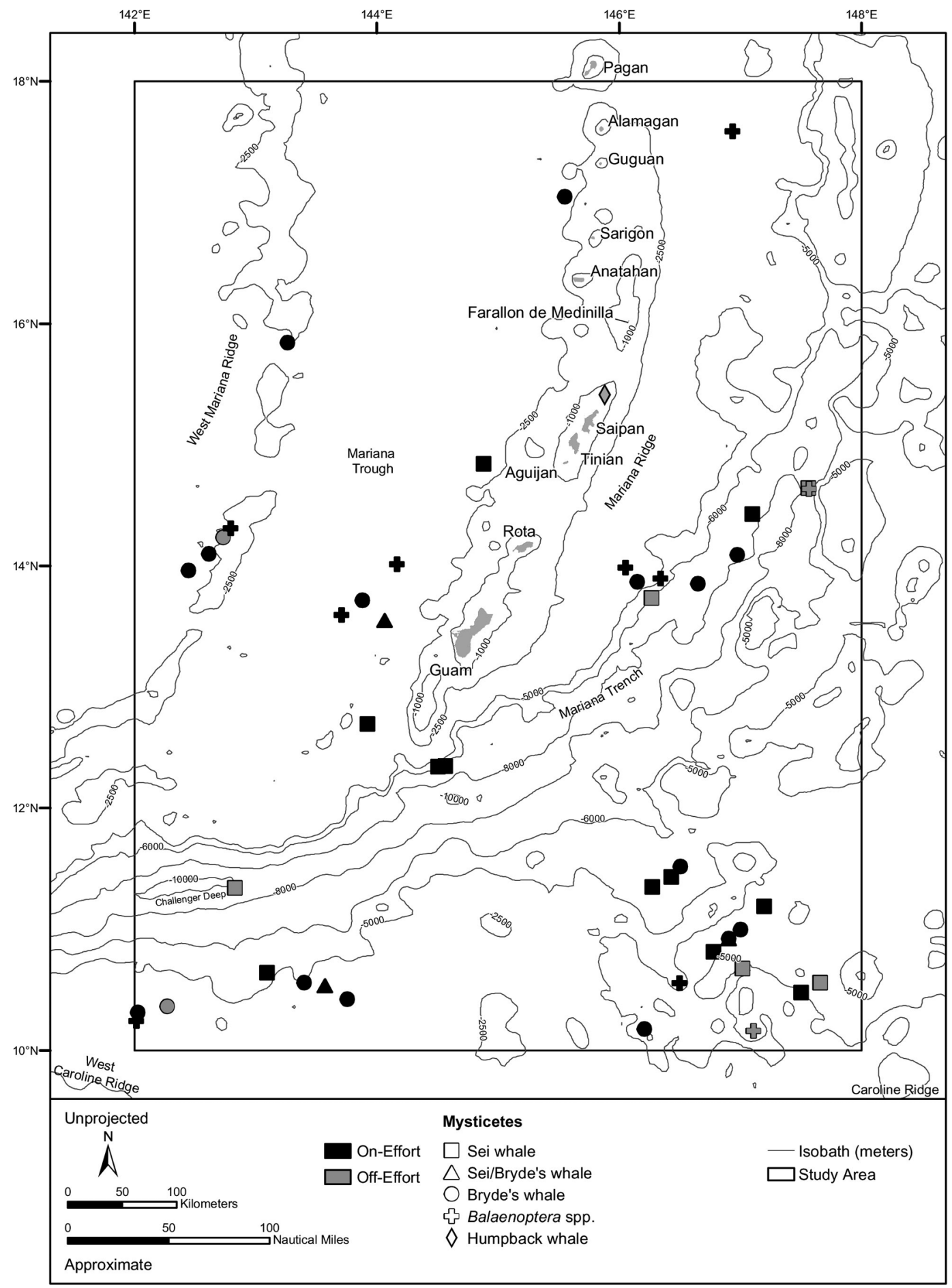

FIGURE 6. Locations of all baleen whale sightings made during the 2007 MISTCS survey. 


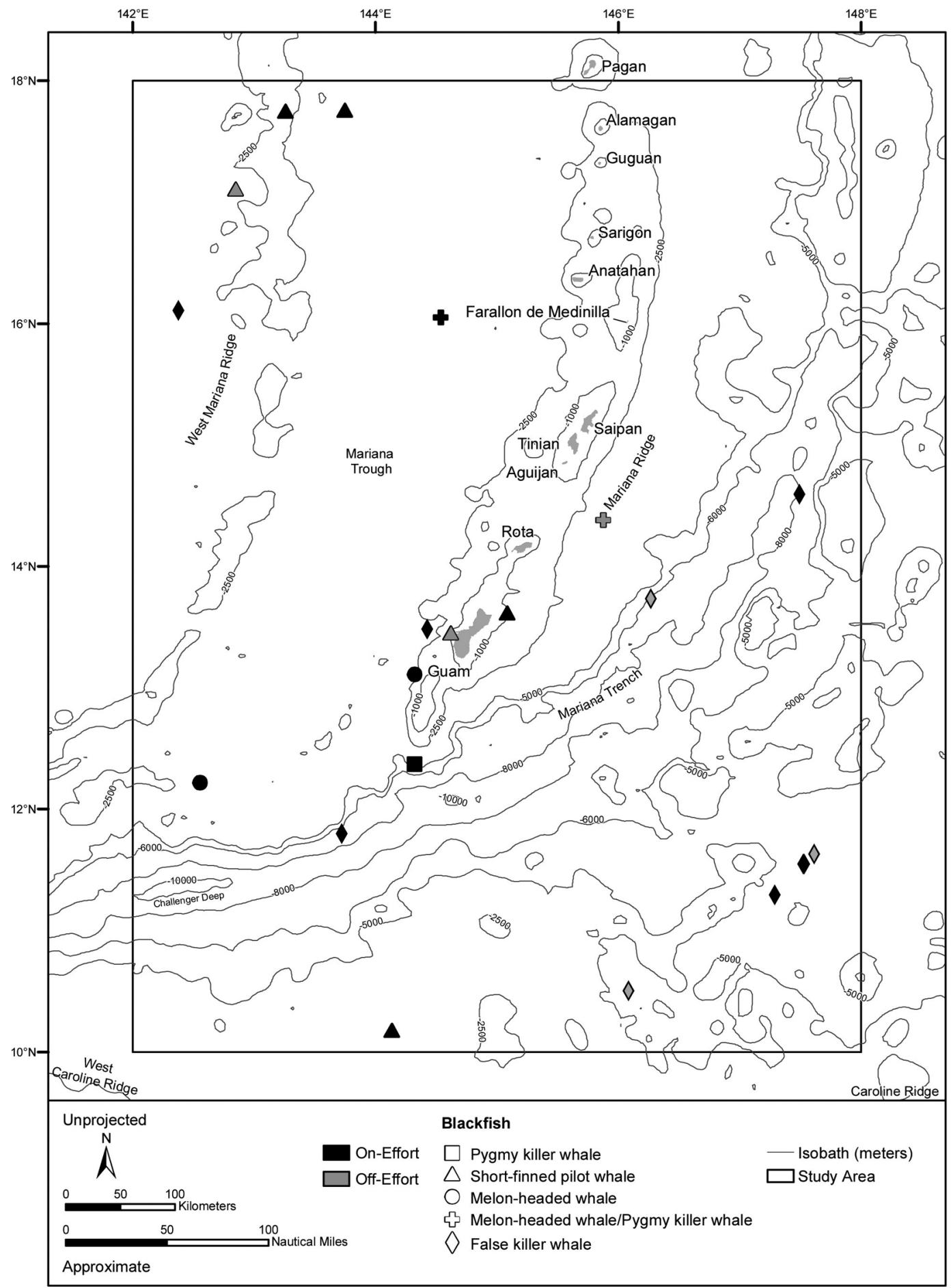

FIgURE 7. Locations of all blackfish sightings made during the 2007 MISTCS survey. 


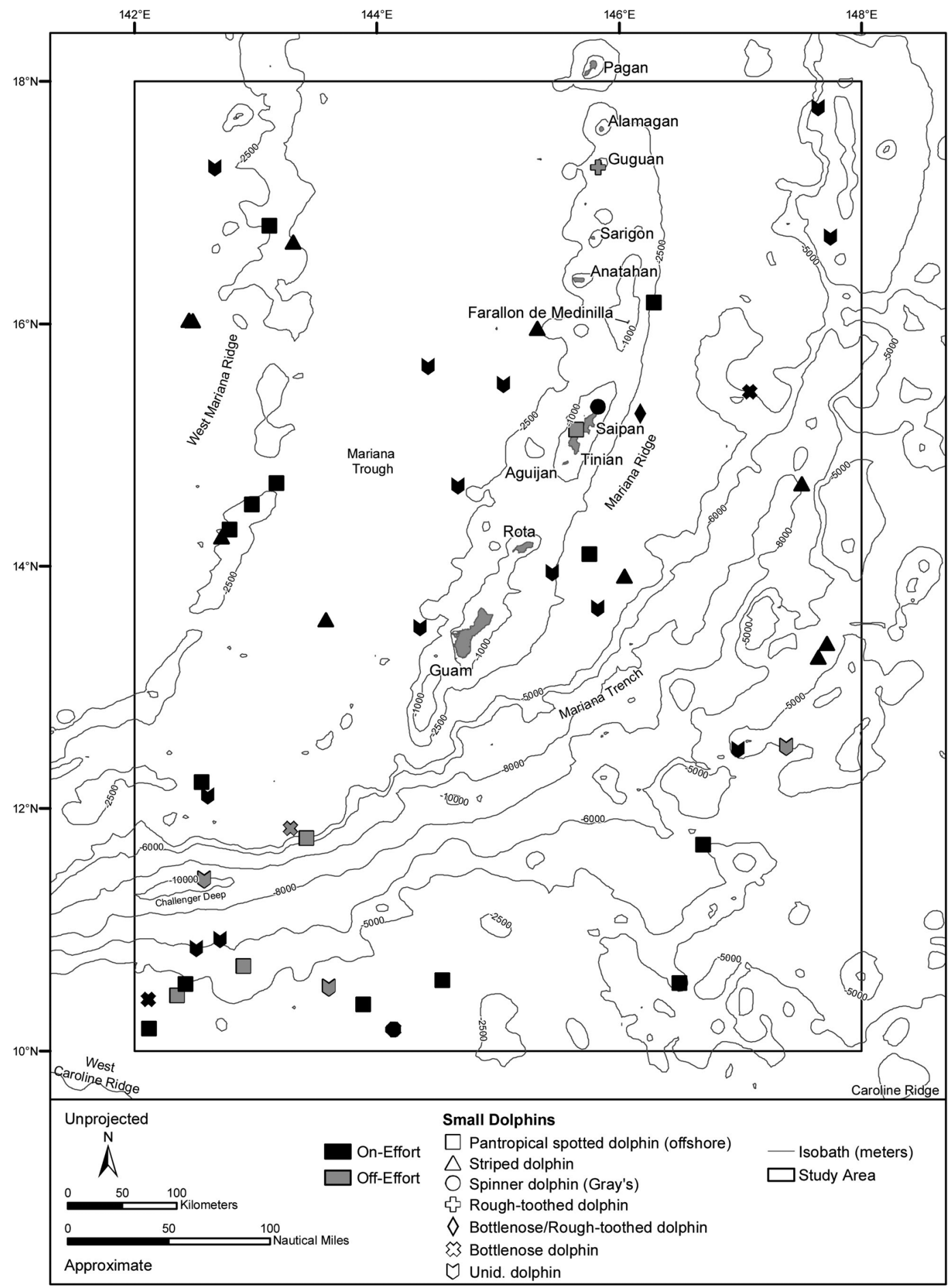

FIGURE 8. Locations of all dolphin sightings made during the 2007 MISTCS survey. 
TABLE 3

Summary of Species/Species Groups with Group Size Range, Mean Group Size (SE = Standard Error), Depth Range and Mean Bottom Depth (in $\mathrm{m}$ ) for All (On- and Off-Effort) Sightings

\begin{tabular}{|c|c|c|c|c|}
\hline Species/Species Group & $\begin{array}{c}\text { Group } \\
\text { Size Range }\end{array}$ & $\begin{array}{l}\text { Mean Group } \\
\text { Size (SE) }\end{array}$ & $\begin{array}{c}\text { Depth } \\
\text { Range (m) }\end{array}$ & $\begin{array}{l}\text { Mean Depth } \\
\quad(\mathrm{m})(\mathrm{SE})\end{array}$ \\
\hline Sperm whale & $1-25$ & $5.1(2.03)$ & $809-9,874$ & $3,925(440.4)$ \\
\hline \multicolumn{5}{|l|}{ Balaenoptera spp. } \\
\hline Sei whale & $1-4$ & $1.3(0.16)$ & $3,164-9,322$ & $5,673(364.2)$ \\
\hline Bryde's whale & $1-3$ & $1.4(0.16)$ & $2,549-7,373$ & $4,563(329.4)$ \\
\hline Sei/Bryde's whale & 1 & 1 & $3,435-4,885$ & $4,531(559.6)$ \\
\hline Unident. Balaenoptera & $1-3$ & 1 & $2,413-7,543$ & $4,334(430.2)$ \\
\hline \multicolumn{5}{|l|}{ Blackfish } \\
\hline False killer whale & $2-26$ & $9.8(4.2)$ & $3,059-8,058$ & $5,617(443.3)$ \\
\hline Short-finned pilot whale & $5-43$ & $17.5(8.8)$ & $927-4,490$ & $2,949(705.4)$ \\
\hline Melon-headed whale & $80-109$ & $94.5(14.5)$ & $3,224-3,935$ & $3,650(161.9)$ \\
\hline Pygmy killer whale & 6 & 6 & 4,439 & - \\
\hline \multicolumn{5}{|l|}{ Small dolphins } \\
\hline Offshore spotted dolphin & $1-115$ & $64.2(37.0)$ & $114-5,672$ & $3,720(354.0)$ \\
\hline Striped dolphin & $7-44$ & $27.4(9.4)$ & $2,362-7,570$ & $4,207(514.5)$ \\
\hline Spinner dolphin & 98 & 98 & 426 & - \\
\hline Rough-toothed dolphin & $7-15$ & 9 & $1,019-4,490$ & $2,755(1,735.5)$ \\
\hline Bottlenose dolphin & $3-10$ & $2.2(1.8)$ & $4,241-5,011$ & $4,554(162.7)$ \\
\hline Bottlenose/rough-toothed dolphin & 3 & 3 & 3,295 & - \\
\hline Unident. dolphins & $1-7$ & $3.7(1.2)$ & $2,418-9,874$ & $4,965(536.8)$ \\
\hline \multicolumn{5}{|l|}{ Other Cetaceans } \\
\hline Megaptera novaeangliae & 8 & - & 148 & - \\
\hline Beaked whales & 1 & - & $2,122-3,984$ & $3,116.7(541.3)$ \\
\hline
\end{tabular}

Note: Mean group size was calculated from on-effort data used in DISTANCE analyses. Mean group size is not comparable with group size, because off-effort sightings were not included in this calculation. Common names separated by / indicate uncertainty in identification.

TABLE 4

Estimate of $f_{i}(0)$ for Each Species Category

\begin{tabular}{|c|c|c|c|c|c|}
\hline Species/Species Group & $n$ & Truncation (m) & $f_{i}(0)\left(\mathrm{m}^{-1}\right)$ & $\mathrm{CV}\left[f_{i}(0)\right]$ & $\mathrm{ESW}^{a}(\mathrm{~m})$ \\
\hline Sperm whale & 11 & 4,000 & $0.858 \mathrm{E}-3$ & 17.6 & 2,053 \\
\hline $\begin{array}{l}\text { Balaenoptera spp. } \\
\text { Sei whale } \\
\text { Bryde's whale } \\
\text { Sei/Bryde's whale } \\
\text { Unident. Balaenoptera }\end{array}$ & 24 & 3,500 & $0.640 \mathrm{E}-3$ & 20.6 & 1,562 \\
\hline $\begin{array}{l}\text { Blackfish } \\
\text { False killer whale } \\
\text { Short-finned pilot whale } \\
\text { Melon-headed whale } \\
\text { Pygmy killer whale }\end{array}$ & 12 & 4,000 & $0.500 \mathrm{E}-3$ & 16.8 & 2,000 \\
\hline $\begin{array}{l}\text { Small dolphins } \\
\text { Offshore spotted dolphin } \\
\text { Striped dolphin } \\
\text { Spinner dolphin } \\
\text { Rough-toothed dolphin } \\
\text { Bottlenose dolphin } \\
\text { Bottlenose/rough-toothed dolphin } \\
\text { Unident. dolphins } \\
\text { Total }\end{array}$ & 33 & 2,500 & $0.708 \mathrm{E}-3$ & 9.9 & 1,412 \\
\hline
\end{tabular}

Note: Species pooled to estimate $f_{i}(0)$ for species categories (e.g., Blackfish) are listed.

${ }^{a}$ ESW, effective half-strip width, $1 / f_{i}(0)$. 
TABLE 5

Density and Abundance Estimates and Group Size for Cetaceans in Guam and CNMI Waters

\begin{tabular}{lccccrcc}
\hline \hline Species & $n$ & $\mathrm{~S}$ & $\mathrm{CV}(\mathrm{S})$ & $\mathrm{D}$ & $N$ & $\mathrm{CV}$ & $\mathrm{CI}(N)$ \\
\hline Sperm whale & 11 & 5.1 & 0.402 & 1.23 & 705 & 0.604 & $228-2,181$ \\
Balaenoptera spp. & 24 & - & - & 0.88 & 499 & 0.328 & $265-941$ \\
$\quad$ Sei whale & 8 & 1.3 & 0.131 & 0.29 & 166 & 0.487 & $67-416$ \\
Bryde's whale & 10 & 1.4 & 0.117 & 0.41 & 233 & 0.450 & $99-546$ \\
Sei/Bryde's whale & 2 & 1 & - & 0.056 & 33 & 1.002 & $6-175$ \\
$\quad$ Unident. Balaenoptera & 4 & 1 & - & 0.12 & 67 & 0.536 & $25-181$ \\
Blackfish & 12 & - & - & 7.12 & 4,079 & 0.938 & $1,650-10,085$ \\
False killer whale & 5 & 9.8 & 0.429 & 1.11 & 637 & 0.743 & $164-2,466$ \\
Short-finned pilot whale & 4 & 17.5 & 0.501 & 1.59 & 909 & 0.677 & $230-3,590$ \\
Melon-headed whale & 2 & 94.5 & 0.153 & 4.28 & 2,455 & 0.702 & $695-8,677$ \\
Pygmy killer whale & 1 & 6 & - & 0.14 & 78 & 0.881 & $17-353$ \\
Small dolphins & 33 & - & - & 33.6 & 19,269 & 0.498 & $7,286-50,959$ \\
$\quad$ Offshore spotted dolphin & 11 & 64.2 & 0.576 & 22.6 & 12,981 & 0.704 & $3,446-48,890$ \\
Striped dolphin & 7 & 27.4 & 0.344 & 6.16 & 3,531 & 0.540 & $1,250-9,977$ \\
Bottlenose dolphin & 3 & 2.2 & 0.807 & 0.21 & 122 & 0.992 & $5.0-2,943$ \\
Spinner dolphin & 1 & 98 & - & 3.14 & 1,803 & 0.958 & $361-9,004$ \\
Rough-toothed dolphin & 1 & 9 & - & 0.29 & 166 & 0.892 & $36-761$ \\
Bottlenose/rough-toothed dolphin & 1 & 3 & - & 0.09 & 55 & 0.918 & $12-262$ \\
Unident. delphinid & 9 & 3.7 & 0.330 & 1.07 & 612 & 0.478 & $242-1,550$ \\
\hline
\end{tabular}

Note: $n=$ number of groups sighted; $\mathrm{S}=$ mean group size; $\mathrm{D}=$ animals $/ 1,000 \mathrm{~km}^{2} ; N=$ number of animals; $\mathrm{CV}=$ coefficient of variation; $\mathrm{CI}=$ confidence interval.

conducted a 5-day aerial survey during August 2007 in our study area south and east of Guam. Cetacean species sighted during that survey included some cryptic species including dwarf/pygmy sperm whales (Kogia spp.), a Cuvier's beaked whale (Ziphius cavirostris), as well as Bryde's whales, pantropical spotted dolphins, and rough-toothed dolphins. The relatively calm sea states (mean Beaufort sea state $=2.2$ ) during the Mobley (2007) survey allowed the detection of cryptic species in the study area, species that were not seen during our survey due to high sea states.

\section{Abundance}

Despite the low number of sightings, we estimated abundance for several cetacean species and groups. This survey was designed to meet the assumptions of line-transect theory (Buckland et al. 2001). However, the abundance estimates are likely negatively biased because the assumption that all cetacean groups on the transect line are detected (i.e., $g(0)=1$ ) certainly was not met since all animals were not available at the surface, and data were not col- lected to correct estimates for perception and availability bias (Thomsen et al. 2005).

For the purpose of this paper, we assumed $g(0)=1$, because estimates of $g(0)$ were not available for the cetaceans in the MISTCS study area or for the survey platform. The probability of detecting an object that is on a transect line, $g(0)$, is very important to generating reliable abundance estimates. Departures of $g(0)$ from 1 can be attributed to either: (a) perception bias (when observers fail to detect an animal on the trackline) or (b) availability bias (from animals being submerged while on the trackline and unable to be detected) (Marsh and Sinclair 1989).

\section{Species Richness and Distribution}

The most interesting finding was the occurrence of sei whales south of $20^{\circ} \mathrm{N}$. Sei whales have a worldwide distribution but are found primarily in cold temperate to subpolar latitudes, rather than in the tropics or near the poles (Horwood 1987). Winter distribution of North Pacific sei whales is poorly understood (Horwood 1987), and breeding/calving 
grounds have not been located (Smultea et al. 2010). Several sightings of sei whales have been recorded in the Hawaiian Islands (e.g., Barlow 2006, Smultea et al. 2010). During January 1972, Japanese researchers "tagged" two sei whales in the general vicinity of the CNMI (1,515 km northwest of Ritidian Point, Guam) (Masaki 1972, Ohsumi and Masaki 1975); these individuals were later killed a few hundred kilometers south of the western Aleutian Islands during June 1972 (Ohsumi and Masaki 1975, Horwood 1987). As noted by Reeves et al. (1999), reports in the literature from any time before the mid-1970s are suspect because of the frequent failure to distinguish sei from Bryde's whales, particularly in tropical to warm temperate waters where Bryde's whales are generally more common than sei whales. Because no identifying characteristics of the whales were provided by the Japanese researchers, it is not possible to confirm whether correct species identification was made. Further complicating the picture is that the sei whale is known for occasional irruptive occurrences in areas followed by disappearances for sometimes decades (Horwood 1987, Schilling et al. 1992, Clapham et al. 1997). Only further survey effort will reveal whether the sei whale is a regular part of the cetacean community of the Marianas region, or whether the observations recorded during our survey were an unusual occurrence.

The value of an acoustic component to shipboard surveys was particularly evident for determining occurrence of two species in the area: minke and humpback whales. The minke whale was not seen, but the species was detected acoustically ("boing" type vocalization) near the Mariana Trench (Department of the Navy 2007, Norris et al. 2007, Oswald et al. 2008). Difficulty in visual detection of the minke whale in the Pacific is not surprising given the rough weather (Rankin and Barlow 2005).

The MISTCS cruise acoustically detected humpback whales; calls were localized, and focal work (including photo-identification) took place $15 \mathrm{~km}$ off the northeast coast of Saipan. The winter range of the Western North Pacific stock of humpback whales has been suggested to extend at least occasionally into the Marianas (e.g., Darling and Mori 1993, Jefferson et al. 2008). Townsend (1935) indicated that many humpbacks were caught off the Marianas, but later attempts to determine occurrence of the species in the area suggested that these whales were no longer common there.

Humpback whales were sighted off Saipan during MISTCS, where tail-slapping, breaching, and chin-slapping were documented. $\mathrm{Al}$ though no calves were observed, these are social behaviors frequently observed on the breeding grounds of the species (e.g., Clapham et al. 1992, Pack et al. 1998). Humpbacks were also acoustically detected by their song; which is commonly heard on the breeding and feeding grounds. Cow-calf occurrence in the CNMI region has been documented (e.g., Department of the Navy 2005). For example, a cow-calf pair was sighted in late February 1991 off the east coast of Rota (Eldridge 2003). Further research efforts would help determine whether this area is commonly used as a breeding ground, or if these are just wayward individuals.

The MISTCS cruise had several sightings of cow-calf pairs for the sperm whale, sei whale, and Bryde's whale. A review of the literature (see Department of the Navy 2005) already noted occurrence of cow-calf pairs of several species for this region. For example, Shimada and Miyashita (2001) reported multiple Bryde's whale cow-calf pairs off Saipan. Eldredge (2003) reported on a 2001 sighting off Guam of a newborn sperm whale calf with the umbilical cord still attached.

\section{Habitat Association}

Associations of cetaceans with steep bathymetric relief including seamounts, undersea ridges, slopes, and deep canyons are often reported. Species exhibiting these associations include sperm whale, short-finned pilot whale, and beaked whales (e.g., Mullin and Fulling 2004, Johnston et al. 2006, Kaschner 2007, Morato et al. 2008). There were numerous cetacean sightings from our survey that occurred over or near steep bathymetric relief including the West Mariana Ridge, the 
Mariana Ridge, the steep slopes of the Mariana Trench, and several seamounts (Figure 4). During our survey, we found that sperm whales were seen near steep bathymetric relief; sei and Bryde's whales were seen near underwater ridges and in an area between the Chamorro seamounts and the start of the Caroline Ridge; two of the three sightings of beaked whales occurred over the northern end of the west Mariana Ridge near a few unnamed seamounts; and there were several sightings of delphinids near slopes and seamounts.

Tropical waters are often areas of low productivity due to the reduced nutrient loads associated with strong currents; the Mariana archipelago is an oligotrophic region (Sandwell et al. 2003). The seamount topography in the Marianas is a striking contrast to the surrounding flat, abyssal plain of the Mariana Trough. The effects seamounts can impart on local ocean circulation are complex and poorly understood (Kaschner 2007). However, increased levels of phytoplankton, primary production, pelagic and demersal fish, and top-level predators (e.g., marine mammals, sea turtles, seabirds) around seamounts are correlated with current pattern alterations and Taylor columns (circulation vortices) (e.g., Rogers 1994, Kaschner 2007). These oceanographic features appear to be very important to the species richness of these regions and deserve further study.

\section{CONCLUSIONS}

Our results demonstrate the need for more research in this area using our study as the basis for future work. These data not only serve the U.S. Navy in their environmental stewardship role and assist in environmental planning but provided baseline data invaluable to other governmental agencies, including the NMFS. NMFS' interest in the Mariana archipelago includes information needs for stock assessment evaluations, marine mammal take permit reviews and other environmental planning purposes, and management of human interactions with cetaceans in the area. The public's interactions with cetaceans in CNMI include dolphin watching and swimming with dolphins and whales (Pacific Islands Fisheries Science Center 2006), which are currently not monitored.

The abundance estimates, species richness, and distribution data provided from this study are the first attempt to systematically assess the cetacean community in the waters near Guam and CNMI. Although probably of low precision and underestimated, our abundance estimates provide the first actual baseline data for the management of several species that occur in the region. Therefore, the MISTCS data (although only a snapshot) serve as the best scientific data in the region and provide invaluable baseline information for the management of cetaceans in this region.

\section{ACKNOWLEDGMENTS}

We thank the observers (J. Cotton, C. Cutler, M. Force, C. Oedekoven, R. Rowlett, J. C. Salinas, B. Phillips, and A. Ü) for their dedication in rough seas. The crew of the $\mathrm{M} / \mathrm{V}$ Kahana, Ed Morris, and Mark Delventhal (P\&R Water Taxi Ltd., Honolulu) worked diligently to make the survey a success. We are also appreciative of the crucial planning and assistance provided by K. Sawyer, J. See, C. Watterson, and P. Gehring. The manuscript was improved greatly by edits, literature mining, and suggestions made by E. Becker, A. Douglas, and D. Fertl. All maps were created with the expertise of K. Knight. Our abundance analyses were greatly improved by suggestions and comments provided by E. Rexstad with the Research Unit for Wildlife Population Assessment (UK) (RUWPA). Finally, we are grateful for discussions, suggestions, and input provided by J. Barlow, K. Forney, and T. A. Jefferson, whose insights improved this study greatly. Contracting oversight was provided by the Naval Facilities Engineering Command (NAVFAC) Pacific. C. Hubard, P. Opay, and M. Payne were very helpful with permit discussions for this survey. The methods used on this survey did not require a NMFS Scientific Research Permit because animals were viewed from $100 \mathrm{~m}$ or greater. When animals approached the ship or were within the $100 \mathrm{~m}$ viewing 
buffer, the ship speed was reduced to steerage to minimize animal interactions. Julie Rivers was the Navy technical representative at NAVFAC Pacific in 2007 for this data collection effort.

\section{Literature Cited}

Akaike, H. 1973. Information theory and an extension of the maximum likelihood principle. Pages 267-281 in B. N. Petrov and F. Csaki, eds. Proceedings of the 2nd International Symposium on Information Theory. Akadémiai Kiadó, Budapest, Hungary.

Barlow, J. 1995. The abundance of cetaceans in California waters. Part I: Ship surveys in summer and fall of 1991. Fish. Bull. 93:114.

1999. Trackline detection probability for long-diving whales. Pages 209-221 in G. W. Garner, S. C. Amstrup, J. L. Laake, B. F. J. Manly, L. L. McDonald, and D. G. Robertson, eds. Marine mammal survey and assessment methods. A. A. Balkema, Rotterdam, The Netherlands.

- 2006. Cetacean abundance in Hawaiian waters estimated from a summer/fall survey in 2002. Mar. Mam. Sci. 22:446-464.

Barlow, J., and B. Taylor. 2005. Estimates of sperm whale abundance in the northeastern temperate Pacific from a combined acoustic and visual survey. Mar. Mam. Sci. 21:429-445.

Buckland, S. T., D. R. Anderson, K. P. Burnham, J. L. Laake, D. L. Borchers, and L. Thomas. 2001. Introduction to distance sampling: Estimating abundance of biological populations. Oxford University Press, New York.

— pling. Oxford University Press, New York.

Clapham, P., S. Leatherwood, I. Szczepaniak, and R. L. Brownell Jr. 1997. Catches of humpback and other whales from shore stations at Moss Landing and Trinidad, California, 1919-1926. Mar. Mam. Sci. 13:368-394.

Clapham, P. J., P. J. Palsbøll, D. K. Mattila, and O. Vasquez. 1992. Composition and dynamics of humpback whale competitive groups in the West Indies. Behaviour 122:182-194.

Darling, J. D., and K. Mori. 1993. Recent observations of humpback whales (Megaptera novaeangliae) in Japanese waters off Ogasawara and Okinawa. Can. J. Zool. 71:325333.

Department of the Navy. 2005. Marine resources assessment for the Marianas Operating Area: Final report. Contract number N62470-02-D-9997, CTO 0027. Pacific Division, Naval Facilities Engineering Command, Pearl Harbor, Hawai'i (https:// portal.navfac.navy.mil/portal/page/portal/ navfac/navfac_ww_pp/navfac_hq_pp/ navfac_environmental/mra).

. 2007. Marine mammal and sea turtle survey and density estimates for Guam and the Commonwealth of the Northern Mariana Islands. Final report, contract no. N68711-02-D-8043. Prepared for U.S. Navy, Pacific Fleet, Naval Facilities Engineering Command, Pacific, Honolulu, Hawai'i (http://www.nmfs.noaa.gov/pr/ pdfs/permits/mirc_mistcs_report.pdf).

Donaldson, T. J. 1983. Further investigations of the whales Peponocephala electra and Globicephala macrorbynchus reported from Guam. Micronesica 19:173-181.

Eldredge, L. G. 1988. A survey of the marine mammals of Micronesia. Report UNEP(OCA)/MM WG.2/INF.6. United Nations Environment Programme, Nairobi, Kenya.

- 1991. Annotated checklist of the marine mammals of Micronesia. Micronesica 24:217-230.

- 2003. The marine reptiles and mammals of Guam. Micronesica 35-36:653660.

Genin, A., and J. F. Dower. 2007. Seamount plankton dynamics. Pages 85-100 in T. J. Pitcher, T. Morato, P. J. B. Hart, M. R. Clark, N. Haggan, and R. S. Santos, eds. Seamounts: Ecology, fisheries and conservation. Blackwell Publishing, Oxford, United Kingdom.

Gerrodette, T., and J. Forcada. 2005. Nonrecovery of two spotted and spinner dol- 
phin populations in the eastern tropical Pacific Ocean. Mar. Ecol. Prog. Ser. 291:1-21.

Gilmartin, M., and N. Revelante. 1974. The 'island mass' effect on the phytoplankton and primary production of the Hawaiian Islands.J. Exp. Mar. Biol.Ecol. 16:181-204.

Horwood, J. 1987. The sei whale: Population biology, ecology and management. Croom Helm in association with Methuen, Inc., New York.

Jefferson, T. A., D. Fertl, M. Michael, and T. D. Fagin. 2006. An unusual encounter with a mixed school of melon-headed whales (Peponocephala electra) and roughtoothed dolphins (Steno bredanensis) at Rota, Northern Mariana Islands. Micronesica 38:239-244.

Jefferson, T. A., M. A. Webber, and R. Pitman. 2008. Marine mammals of the world: A comprehensive guide to their identification. Academic Press, San Diego, California.

Johnston, D. W., M. McDonald, J. Polovina, R. Domokos, S. Wiggins, and J. Hildebrand. 2006. Temporal patterns in the acoustic signals of beaked whales at Cross Seamount. Biol. Lett. 4:208-211.

Kami, H. T., and A. J. Hosmer. 1982. Recent beachings of whales on Guam. Micronesica 18:133-135.

Kami, H. T., and R. J. Lujan. 1976. Records of the dwarf sperm whale Kogia simus Owen from Guam. Micronesica 12:327-332.

Kaschner, K. 2007. Air-breathing to seamounts: Marine mammals. Pages 230-238 in T. J. Pitcher, T. Morato, P. J. B. Hart, M. R. Clark, N. Haggan and R. S. Santos, eds. Seamounts: Ecology, fisheries and conservation. Blackwell Publishing, Oxford, United Kingdom.

Lerczak, J. A., and R. C. Hobbs. 1998. Calculating sighting distances from angular readings during shipboard, aerial, and shore-based marine mammal surveys. Mar. Mam. Sci. 14:590-599.

Marsh, H., and D. F. Sinclair. 1989. Correcting for visibility bias in strip transect aerial surveys of aquatic fauna. J. Wildl. Manage. 53:1017-1024.
Masaki, Y. 1972. Tagging investigations of whales in Osasawara and Mariana Islands. Geiken Tsushin (News of the Whales Research Instititute) 249:35-42.

Miyazaki, N., and S. Wada. 1978. Observation of cetacean during whale marking cruise in the western tropical Pacific. Sci. Rep. Whales Res. Inst. Tokyo 20:179-195.

Mobley, J. 2007. Marine mammal monitoring surveys in support of "Valiant Shield" training exercises (Aug. 13-17, 2007). Final report submitted to Environmental Division, Commander, U.S. Navy, Pacific Fleet (http://socrates.uhwo.hawaii.edu/ SocialSci/jmobley/07Guamreport.pdf).

Morato, T., D. A. Varkey, C. Damaso, M. Machete, M. Santos, R. Prieto, R. S. Santos, and T. J. Pitcher. 2008. Evidence of a seamount effect on aggregating visitors. Mar. Ecol. Progr. Ser. 357:23-32.

Mullin, K. D., and G. L. Fulling. 2004. Abundance of cetaceans in the oceanic northern Gulf of Mexico, 1996-2001. Mar. Mam. Sci. 20:787-807.

Norris, T., A. Azzara, L. Morse, G. Fulling, T. Yack, and P. Thorson. 2007. Acoustic detections of fourteen species of cetaceans off the Northern Mariana Islands: Results of a three month acoustic and visual linetransect survey in the western North Pacific. Abstracts, Seventeenth Biennial Conference on the Biology of Marine Mammals. Cape Town, South Africa, 29 November to 3 December 2007.

Ohizumi, H., T. Matsuishi, and H. Kishino. 2002. Winter sightings of humpback and Bryde's whales in tropical waters of the western and central and North Pacific. Aquat. Mamm. 28:73-77.

Ohsumi, S., and Y. Masaki. 1975. Japanese whale marking in the North Pacific, 19631972. Bull. Far Seas Fish. Res. Lab. (Shimizu) 12:171-219.

Omura, H., and T. Kawakami. 1956. Japanese whale marking in the North Pacific. Nor. Hval.-Tidend. 10:555-563.

Oswald, J., T. Norris, W. Au, and F. Duennebier. 2008. Temporal and geographic patterns in the occurrence and distribution of minke whale (Balaenoptera acutorostrata) 
boings in the central and western North Pacific. J. Acoust. Soc. Am. 24:2484.

Pacific Islands Fisheries Science Center. 2006. Report: Workshop on Research Needs for the Conservation and Management of Cetaceans in the Pacific Islands Region. PIFSC Special Publication SP-06002. Pacific Islands Fisheries Science Center, Honolulu, Hawai'i.

Pack, A. A., D. R. Salden, M. J. Ferrari, D. A. Glockner-Ferrari, L. M. Herman, H. A. Stubbs, and J. M. Straley. 1998. Male humpback whale dies in competitive group. Mar. Mam. Sci. 14:861-873.

Palacios, D. M., S. J. Bograd, D. G. Foley, and F. B. Schwing. 2006. Oceanographic characteristics of biological hot spots in the North Pacific: A remote sensing perspective. Deep-Sea Res. II 53:250-269.

Pickard, G. L., and W. J. Emery. 1982. Descriptive physical oceanography: An introduction. 4th ed. Pergamon Press, Oxford, England.

Rankin, S., and J. Barlow. 2005. Source of the North Pacific "boing" sound attributed to minke whales. J. Acoust. Soc. Am. 118:3346-3351.

Reeves, R. R., S. Leatherwood, G. S. Stone, and L. G. Eldredge. 1999. Marine mammals in the area served by the South Pacific Regional Environment Programme (SPREP). South Pacific Regional Environment Programme, Apia, Samoa.

Rogers, A. D. 1994. The biology of seamounts. Pages 304-364 in J. H. Blaxter and A. J. Southward, eds. Advances in marine biology. Academic Press, San Diego, California.

Sandwell, D. T., S. T. Gille, and W. H. F. Smith, eds. 2003. Bathymetry from space: Oceanography, geophysics, and climate. Geoscience Professional Services, Bethesda, Maryland.

Sarmiento, J. L., N. Gruber, M. A. Brzezinski, and J. P. Dunne. 2004. High-latitude controls of thermocline nutrients and low latitude biological productivity. Nature (Lond.) 427:56-60.

Schilling, M. R., I. Seipt, M. T. Weinrich, S. E. Frohock, A. E. Kuhlberg, and P. J. Clapham. 1992. Behavior of individually- identified sei whales Balaenoptera borealis during an episodic influx into the southern Gulf of Maine in 1986. Fish. Bull. 90:749755.

Shimada, H., and T. Miyashita. 2001. Report of the sighting surveys for winter distribution of large cetaceans in the low latitudinal waters of the western North Pacific, 1999-2001. Working Document SC/53/ RMP10 submitted to the Scientific Committee of the International Whaling Commission, 23-27 July, London, England (http://iwcoffice.org/_documents/sci _com/workshops/MSYR/SC-53-RMP10 .pdf).

Shimada, H., H. Okamura, T. Kitakado, and T. Miyashita. 2008. Abundance estimate of western North Pacific Bryde's whales for the estimation of additional variance and CLA application. Working document SC/60/PFI2 submitted to the Scientific Committee of the International Whaling Commission, 13-27 June, Santiago, Chile (http://iwcoffice.org/_documents/sci _com/SC60docs/SC-60-PFI2.pdf).

Simpson, J. H., P. B. Tett, M. L. ArgoteEspinoza, A. Edwards, K. J. Jones, and G. Savidge. 1982. Mixing and phytoplankton growth around an island in a stratified sea. Cont. Shelf Res. 1:15-31.

Smultea, M. A., T. A. Jefferson, and A. M. Zoidis. 2010. Rare sightings of a Bryde's whale (Balaenoptera edeni) and sei whales (B. borealis) (Cetacea: Balaenopteridae) northeast of $\mathrm{O}^{6}$ ahu, Hawai'i. Pac. Sci. 64:449-457.

Thomas, L., J. L. Laake, E. Rexstad, S. Strindberg, F. F. C. Marques, S. T. Buckland, D. L. Borchers, D. R. Anderson, K. P. Burnham, M. L. Burt, S. L. Hedley, J. H. Pollard, J. R. B. Bishop, and T. A. Marques. 2006. Distance 6.0. Release Beta 1. Research Unit for Wildlife Population Assessment, University of St. Andrews, St. Andrews, Scotland (http://www.ruwpa.st -and.ac.uk/distance/).

Thomsen, F., F. Ugarte, and P. G. H. Evans, eds. 2005. Proceedings of the workshop on estimation of $g(0)$ in line-transect surveys of cetaceans held at the European Cetacean Society's 18th Annual Conference, 
Vildmarkshotellet at Kolmården Djur Park, Kolmården, Sweden, 28 March 2004. ECS Newsletter 44 (Special Issue).

Townsend, C. H. 1935. The distribution of certain whales as shown by logbook records of American whaleships. Zoologica (N.Y.) 19 (1): 3-50.

Trianni, M. S., and C. C. Kessler. 2002. Incidence and strandings of spinner dolphin, Stenella longirostris, in Saipan Lagoon. Micronesica 34:249-260.

Uda, M. 1970. Fishery oceanographic studies of frontal eddies and transport associated with the Kuroshio System including the "Subtropical Countercurrent." Pages 593604 in J. C. Marr, ed. The Kuroshio. EastWest Center Press, Honolulu, Hawai'i.

Wiles, G. J. 2005. A checklist of the birds and mammals of Micronesia. Micronesica 38:141-189.

Wolanski, E., R. H. Richmond, G. Davis, E. Deleersnijder, and R. R. Leben. 2003. Eddies around Guam, an island in the Mariana Islands group. Cont. Shelf Res. 23:991-1003. 
